\title{
Attitudes on Affirmative Action in University Students: Effects of Race, Political Beliefs and Prejudice *
}

\section{Actitudes de las acciones afirmativas en universitarios: Efecto de la raza, creencias políticas y prejuicio}

Received: 26 February 2019 | Accepted: 11 April 2019

\author{
Ronaldo Pilati ${ }^{\mathrm{a}}$ \\ University of Brasilia, Brasil \\ ORCID: http://orcid.org/0000-0003-2982-5033 \\ Mathieu Turgeon \\ University of Western Ontario, Canadá \\ ORCID: http://orcid.org/0000-0003-0134-4027
}

a Corresponding author. Email: rpilati@unb.br

How to cite: Pilati, R., \& Turgeon, M. (2019). Attitudes on affirmative action in university students: effects of race, political beliefs and prejudice. Universitas Psychologica, 18(2), 1-18. https://doi.org/10.11144/Javeriana.upsy18-2.aaau

\begin{abstract}
The interplay between explicit and implicit attitudes toward affirmative action (AA) policies is relevant to applied psychology. Its comprehension helps to improve our capacity to evaluate support for such policies. The purpose of this study was to determine the extent to which students' race, political opinion of affirmative action, and prejudice against minorities influence the relationship between implicit-explicit attitudes toward affirmative action policies. 492 student participants were recruited from a large Brazilian public university about racial quotas in admissions. Implicit and explicit measures of attitude about the admission process were applied, together with measures of political opinion of affirmative action, prejudice against minorities and race. The results show that race has little effect on the difference between implicit and explicit attitudes about the admission process, but that prejudice and political position exert strong effects. Our findings suggest that implicit measures of attitudes should be used when evaluating attitudes on AA.

Keywords

Attitudes; implicit attitudes; explicit attitudes; affirmative action; prejudice; university students.
\end{abstract}

\section{RESUMEN}

La interacción entre las actitudes explícitas e implícitas hacia las políticas de acción afirmativa (AA) es relevante para la psicología aplicada. Su comprensión ayuda a mejorar nuestra capacidad para evaluar el apoyo a tales políticas. El propósito de este estudio fue determinar en qué medida la raza de los estudiantes, la opinión política de la acción afirmativa y el prejuicio contra las minorías influyen en la relación entre las actitudes implícitas y explícitas hacia las políticas de acción afirmativa. 492 estudiantes participantes de una gran universidad pública brasileña fueron encuestados acerca las cuotas raciales en las admisiones. Se aplicaron medidas de actitud implícita y explícita sobre el proceso de admisión, junto con medidas de opinión política de acción afirmativa, prejuicios contra las minorías y la raza. Los resultados muestran que la raza tiene poco efecto en la diferencia entre las actitudes implícitas y explícitas 
sobre el proceso de admisión, pero que los prejuicios y la posición política ejercen fuertes efectos. Nuestros hallazgos sugieren que se deben usar medidas implícitas de actitudes al evaluar actitudes sobre AA.

Palabras clave

Actitudes; actitudes implícitas; actitudes explícitas; acción afirmativa; prejuicio; universitarios.

Affirmative action (AA) policies are public policies commonly used to address social inequalities, including, most notably, racial inequalities in opportunities (Kravitz et al., 1997). In recent years, Brazil has adopted a series of AA policies aimed at reducing rampant inequalities among whites and nonwhites (Htun, 2004). The most important AA policy in Brazil concerns the use of quotas in admissions to the country's public federal universities. Admission to Brazil's public higher education has always been very competitive. Not surprisingly, access to Brazil's best universities has historically been limited to white middle and upper-class students who were fortunate enough to study in private schools where they were adequately prepared for the admission exam (de Rezende-Pinto, 2004). In recent years, however, many universities have adopted racial quotas for Afro-Brazilians to diversify the university student population (dos Santos, 2012). These initiatives, which began in the early 2000s, led the Brazilian federal government in 2012 to enact a law that created quotas for all federal universities. The new quota system maintained racial quotas, but also created new quotas for low-income students and those from public schools. As a result, a much higher proportion of the student population in public federal universities is now from lower economic strata and non-white.

The new admission policy is designed to ensure that historically disadvantaged social groups gain access to higher education (Telles \& Bailey, 2002; Theodoro, Jaccoud, Osório, \& Soares, 2009). The policy has had an enormous effect on university admissions, affecting the lives of hundreds of thousands of students by facilitating access for some and limiting it for others. Interestingly, not much is known about attitudes toward AA policies in Brazil, as the new university quota system, despite its substantial impact on the social and economic structures of the country. The recent work by Bailey, Fialho and Peria (2015), for example, shows that support among non-whites is higher than that among whites, but this difference washes out when university quotas are framed as a zero-sum game. Earlier work by Telles and Bailey (2002) also finds greater support for university racial quotas among non-whites.

Measuring support for affirmative action policies is not an easy task (Kuklinski et al., 1997). Indeed, racial quotas like other policies related to gender and sexual orientation concern socially sensible issues where individuals may not feel comfortable in publicly expressing their true attitudes, especially if they are at odds with social norms. Thus, measures of explicit attitudes can be biased when applied to socially sensitive issues for social desirability reasons or for the impossibility of one to access the attitude content through introspection. In that case, respondents can under or over-report their attitudes. Most of the previous research about attitudes toward the AA in Brazil and, especially that related to racial quotas, neglected how social desirability affects attitude report. We hope to address, in part, this issue. Recent advances in attitude measurement techniques have proposed indirect measures, like the list and endorsement experiments, that can be adopted to cope or circumvent the bias introduced by social desirability in explicit measures of attitudes.

To be sure, indirect measures of attitudes are better than explicit ones when the issues tapped are socially sensitive. There are more measurement alternatives to address the challenges of evaluating AA policies. The study of implicit processes of political behavior has received attention in recent years (Bos, Sheets, \& Boomgaarden, 2018; Friese, Smith, Koever, \& Bluemke, 2016; Gawronski, Galdi, \& Arcuri, 2015; Ksiazkiewicz, Vitriol, \& Farhart, 2018; Raccuia, 2016; Theodoridis, 2017). The concern is related to issues where social desirability produces strong bias in direct measures of attitudes, as is the case with attitudes on AA policies. The use of indirect measures helps gain a 
better understanding of attitudes on AA policies. There has been relatively little research of implicit social cognitive processes on AA policies, although its importance has been recognized more than 13 years ago (Kang \& Banaji, 2006). Seeking to improve our understanding about implicit attitudes on AA policies, we use both implicit and explicit measures of attitudes toward racial quotas in university admissions and ask: do implicit and explicit measures of attitudes toward racial quotas produce similar results?

Moreover, do whites and non-whites differ in their implicit and explicit attitudes toward racial quotas? If so, how do they differ? And, finally, what determinants explain differences between implicit and explicit measures of attitudes toward racial quotas?

\section{Measurement of Implicit and Explicit Attitudes on AA Policies}

The study of socially sensitive issues has always been a challenge for psychologists. AA policies concern a socially sensitive issue, meaning that respondents frequently have incentives to under or over-represent their true attitudes to make them more in line with social norms. Whites, for example, may over-represent their true support for AA policies when asked directly, by fear of appearing prejudiced against non-whites or unconcerned about racial discrimination and inequalities. Non-whites, for their part, may under-represent their true support when asked directly, by fear of being judged as unconcerned about questions of merit and fairness. When social desirability bias is expected, scholars have frequently adopted indirect measures of attitudes like the list and endorsement experiments to circumvent this social desirability bias in attitude report (Kim \& Kim, 2016; Sniderman \& Grob, 1996; Vidigal, 2018). Turgeon, Chaves and Wives (2014), for example, used a list experiment to measure attitudes about racial quotas in university admissions in Brazil. Their results show that, contrary to expectations, white students do not over-report their support for racial quotas, but that non-white students tend to under- report their support. This study, like others before it, documents the importance of measuring attitudes about sensitive issues adopting indirect measures to avoid over or under-reporting of true attitudes.

In social cognition research, other indirect techniques like the implicit attitudes procedures have been used to measure attitudes on sensitive issues (e.g., Hahn \& Gawronski, 2018). Implicit attitude measures are useful to deal with social desirability, but, more importantly, for present purposes, they help in understanding how the implicit processes influence the support for AA policies, especially in populations directly affected by such policies. To this end, we investigate the interplay between university students' explicit and implicit attitudes on AA in university admission policies. We explore this issue using data from Brazil, a context where there has been little research into social psychological processes and, in particular, about implicit social cognitive processes.

The implicit association test (IAT) is the most commonly used procedure for measuring implicit attitudes and has been used over a broad range of issues (Nosek, Hawkins, \& Frazier, 2011). The IAT also has better psychometric properties than the alternatives and has demonstrated its ability to differentiate groups with previously known attitudes (Bar-Anan \& Nosek, 2012). We adopt the IAT and make use of its discriminative ability to compare implicit and explicit attitudes on university admissions procedures, namely racial quotas and the traditional entry exam (vestibular).

Scholars have demonstrated that the relationship between implicit and explicit measures is affected by many factors (Hofmann, Gschwendner, Nosek, \& Schmitt, 2005). Nosek (2007), for example, shows that the attitude domain influences the relationship between explicit and implicit measures of attitude with higher correlations for attitudes about politics (e.g., party support) and lower correlations in the evaluation of stereotypes or group prejudice (e.g., white's attitudes about blacks). Nosek (2007) shows that more socially sensitive issues, like AA policies, tend to exhibit greater implicit- 
explicit discrepancy. This finding is important because predictive attitude validity is affected by the strength of the association between implicit and explicit measures, with greater discrepancies decreasing attitude predictive validity over behavior (Karpen, Jia, \& Rydell, 2012). Consequently, a greater discrepancy between implicit and explicit attitudes on AA may reduce our ability to predict behaviors related to AA, more generally.

Attitudes on AA policies are thought-out and firmly held by university students because such policies are essential to them. Precisely, Brazilian students are directly concerned about the policy because it affects them directly in significant ways by benefiting non-white students and potentially jeopardizing the access of other racial groups to public universities, namely white students. To be sure, racial quotas in university admissions make racial identity central to understanding support for such policy because students' racial identity (white/nonwhite) directly affects their likelihood of being admitted to the university. The salience of race is thus undeniable to understand students' explicit and implicit support for university admission rules. We expect, like past work in the area, that now-whites will be more supportive of AA policies like racial quotas (Schmermund, Sellers, Mueller, \& Crosby, 2001).

Beyond race, implicit and explicit attitudes on AA policies can also be explained by political beliefs and predispositions (Sniderman, Crosby, $\&$ Howell, 2000). Specifically, there are many reasons why one may support or oppose AA. For example, some value greater equality and diversity and want governments to enact policies like AA to achieve such goals. Others, on the other hand, believe it is best for governments to stay put and let people's fortune be defined solely by merit and self-reliance. Admittedly, such political beliefs and preferences are expected to correlate in similar ways with both implicit and explicit support for AA policies.

Finally, we believe that prejudice against minority groups, in general, may also carry substantial influence on both the implicit and explicit support for AA. Specifically, prejudiced people are generally less supportive of policies targeting minority groups (e.g., Kuklinski et al., 1997), and this pattern should also be observed among prejudiced students.

\section{Predictions}

We tested three variables as correlates of explicit and implicit support for AA and their discrepancy. The first was race. For this variable, we expect that the group that is beneficiary of quotas (i.e., non-whites) will show a more implicit and explicit endorsement of quotas, as compared to whites. We also believe that the discrepancy between implicit and explicit attitudes on AA should be higher between whites and non-whites (because the policy affects them differently) then within each group separately. Among white respondents, however, we expect the implicit measure to be higher than the explicit one for social desirability reasons.

The second concerns political beliefs and predispositions. Students who hold political beliefs and preferences that are more supportive of AA should demonstrate an implicit attitude towards the admission system greater than the explicit one. On the other hand, those holding political beliefs and preferences less supportive of AA should demonstrate more explicit attitude to the admission system than the implicit one. Such a pattern should emerge because the explicit attitude is a strategy to demonstrate one's political beliefs and predispositions on the attitude object, but not necessarily their true attitude about the admission system. These differences between implicit and explicit attitudes arise because individuals have little control over IAT responses, as compared to explicit measures (Steffens, 2004). Overall, we also expect those holding political beliefs and predispositions more supportive of AA to show greater explicit and implicit support of AA, as compared to those holding less supportive political beliefs and predispositions.

The third variable is prejudice against minority groups. Because the quota system is intended to benefit minority social groups, we also expect 
that prejudice against minorities will influence the discrepancy between explicit and implicit evaluations of the admission system, with the less prejudiced showing greater implicit than explicit support for the admission system and the more prejudiced showing the opposite pattern.

To test these three predictions, we developed a correlational design study. We recruited a sample of university students that are directly affected by race quotas in university admissions and applied implicit and explicit measures of attitudes about it. We also collected information about the three independent variables of interest (race, political preferences about AA, and a measure of prejudice). We hope our design can shed some light unto the relationship between implicit-explicit attitudes on AA policies in Brazil, a country where such policies are common currency, but little understood.

\section{Method}

\section{Participants}

The participants are 492 students from various courses at the University of Brasilia: 268 (54.5\%) are female; 254 (51.6\%) are white; 255 (51.8\%) stated that their family had a monthly income of less than R $\$ 7,000.00$ (approx. US\$2,200.00); $307(62.4 \%)$ attended a private high school; $306(62.2 \%)$ entered the university through the traditional system of selection and 56 (11.4\%) entered via racial quotas.

\section{Measures}

IAT development. We developed an IAT to measure the implicit attitude of quotas in university admissions. There are several implicit measurement procedures, but we have decided to adopt the implicit association test (IAT). This procedure is the most commonly used for measuring implicit attitudes and has been applied in a broad range of attitude domains (Nosek et al., 2011). The IAT also has better psychometric properties than the alternatives and has demonstrated the capacity to differentiate groups with previously known attitudes (Bar-Anan \& Nosek, 2012). The development of the IAT was a multi-stage process that included pre-testing in a group of students from the same university as those constituting the experimental sample. The research team began by selecting a set of stimuli associated with the two categories that would be employed in the IAT: racial quotas and the traditional entry exam (vestibular). Fifteen students rated the importance and relevance of the stimuli to each category and, based on these data, we selected eight stimuli for each target category. Stimuli for attribute categories (i.e., pleasant X unpleasant) were selected based on previous research on the valence of Portuguese words (Stein \& Gomes, 2009) that have been employed in other IATs and that are known to be reliable (e.g., Modesto \& Pilati, 2015). We also carried out a pilot study of the IAT with a sample of 35 students from the same university as the main sample. The results indicated that the proposed IAT was adequate and there were no operational problems with the response process. The results of the pilot study indicated that the IAT had the potential to discriminate between groups based on their political preferences about racial quotas and showed good internal consistency $(\alpha=0.78)$. The IAT that was used in this research used the target categories Racial quotas (stimuli: access; inclusion; opportunity; diversity; integration; beneficial; repair; democratization) and Vestibular (stimuli: competitive; multidisciplinary; effort; demanding; challenging; selective; rigor; success). For attribute categories, we used Pleasant (stimuli: freedom; fun; happiness; victory; peace; delight; life; holiday) and Unpleasant (stimuli: misery; poison; tragedy; death; poverty; tumor; disease; cancer). The IAT score was created according to conventional procedures (Greenwald, Nosek, \& Banaji, 2003) and showed acceptable reliability $(\alpha=0.73)$.

Explicit measure of attitude about racial quotas and vestibular. We developed an 11 item scale to evaluate explicit attitudes about racial quotas and the vestibular (item sample: All universities should have a quota system; 
Vestibular ensures better training of students at the university). Precisely, respondents were presented with 11 statements about racial quotas and the vestibular and were asked to indicate on a five-point Likert their level of agreement with each of the said statements. Factor analysis resulted in the extraction of two clearly interpretable factors, attitude about racial quotas $(\alpha=0.93)$ and attitude about the vestibular $(\alpha=0.85)$. We used the 11 items to create a score indicating an explicit preference for the vestibular.

Political beliefs and preferences. We measured students' political beliefs and preferences about race and AA using a series of statements. Respondents were asked to indicate if they agreed with the statements, using a fourpoint Likert scale. The reliability coefficient is good $(\alpha=0.87)$. To create our measure of beliefs and preferences about race and AA, we split the sample in half between those more supportive of racial quotas and those who are less supportive (item sample: There is racism in Brazil; University quotas for black and indigenous people help to correct a past error).

Prejudice against minorities. We evaluated prejudice using a five-item scale of frequently used stereotypical cultural expressions on black people, women, homosexuals, and the poor and low educated. Participants were required to indicate whether they thought the statements were mere jokes or expressions of prejudice. The reliability coefficient is satisfactory $(\alpha=$ 0.63). We considered the classification of said statements as mere jokes as an indication of prejudice. Using the median value of the sum of the five statements, we classified 330 (71\%) respondents as exhibiting low prejudice and 162 (29\%) as exhibiting high prejudice.

\section{Procedure}

The data collection was carried out online using Inquisit Web 4.0. Nearly all 23.000 university students were sent an email inviting them to take part in the survey. Respondents who agreed to participate first completed the IAT next received the explicit measures, and, finally, were asked questions about other political attitudes and some demographic characteristics. Participation was voluntary and responses were guaranteed anonymity.

\section{Results}

The implicit and explicit scores were measured on different metrics. We converted them to a 0-10 scale to facilitate comparison. For both measures, higher scores indicate a preference for the vestibular over the quota system. The mean for the explicit and implicit measures is similar at $5.10(S D=2.44)$ and $5.19(S D=$ 1.62), respectively. Both measures are moderately positively correlated $(r=0.37, p<0.001)$. Both the means and the correlation indicate moderate convergence between the two measures.

We find that the implicit and explicit measures are both affected by race, political preferences, and prejudice, and in ways expected. First, as shown in Figure 1, we find that non-whites demonstrate more support for AA policies, as compared to whites. Specifically, race has a small effect on implicit attitude $(F(1,476)$ $=4.59, p=0.033, r=0.10)$, with white students expressing a greater preference for the vestibular $(M=5.31, S D=1.63)$ than non-white students $(M=4.99, S D=1.61)$. There is also a small effect for race on explicit attitude $(F(1$, $476)=7.20, p=.008, r=0.12$ ), with white students expressing a greater preference for the vestibular $(M=5.36, S D=2.48)$ than non-white students $(M=4.76, S D=2.39)$. Admittedly, the differences are small, but still explain an important difference between whites and nonwhites over the issue of AA. The differences between explicit and implicit measures among whites and non-whites, however, are small and do no reach a conventional level of statistical significance. This result is surprising and does not suggest, contrary to past research in the area, much of an effect for social desirability among white participants. 
Figure 1

Comparison of the explicit and implicit measures about the traditional entry exam (vestibular) among white and non-white students; data shown are means and 95\% confidence intervals.

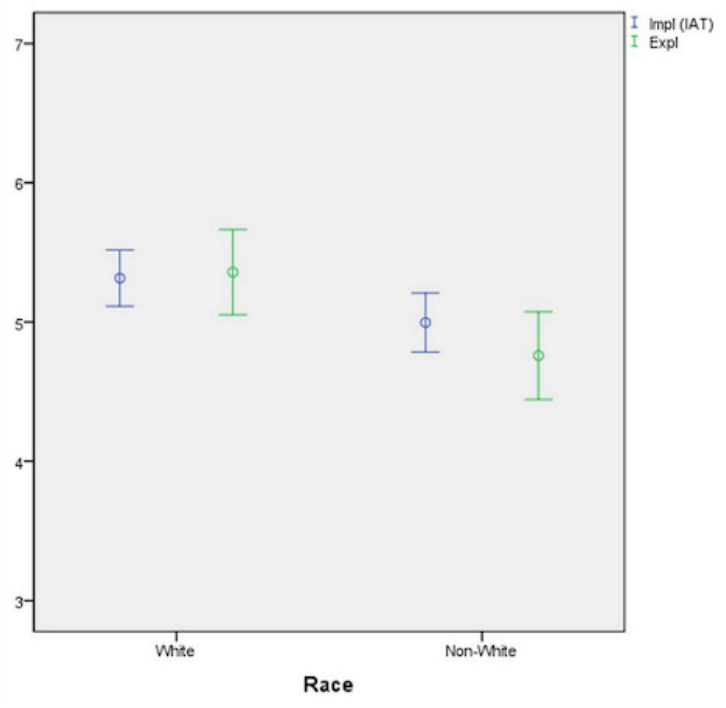

Figure 2 shows a similar analysis but concerns the effect of political preferences about AA on our explicit and implicit measures. Here, we find larger differences than for race. Specifically, support for $\mathrm{AA}$ has a moderate effect on the implicit measure $(F(1,490)=47.16, p<0.001$, $r=0.30$ ), with non-supporters of AA showing a greater implicit preference for the vestibular $(M=5.65, S D=1.44)$ than supporters $(M$ $=4.69, \mathrm{SD}=1.66)$. The effect of support for $\mathrm{AA}$ is even larger for the explicit measure $(F$ $(1,490)=470.23, p<0.001, r=0.70)$, with non-supporters showing a much stronger explicit preference for the vestibular $(\mathrm{M}=6.75, \mathrm{SD}=$ 1.66) than supporters $(M=3.34, S D=1.82)$. The within-group analysis also reveals important differences between our implicit and explicit measures. Specifically, we find that support for AA was strongly related to the magnitude of the difference between the implicit and explicit measures. We find that supporters of AA tend to under-report their explicit attitude about the vestibular while non-supporters tend to overreport it.
Figure 2

Comparison of the explicit and implicit measures about the traditional entry exam (vestibular) among supporters and non-supporters of racial quotas; data shown are means and 95\% confidence intervals.

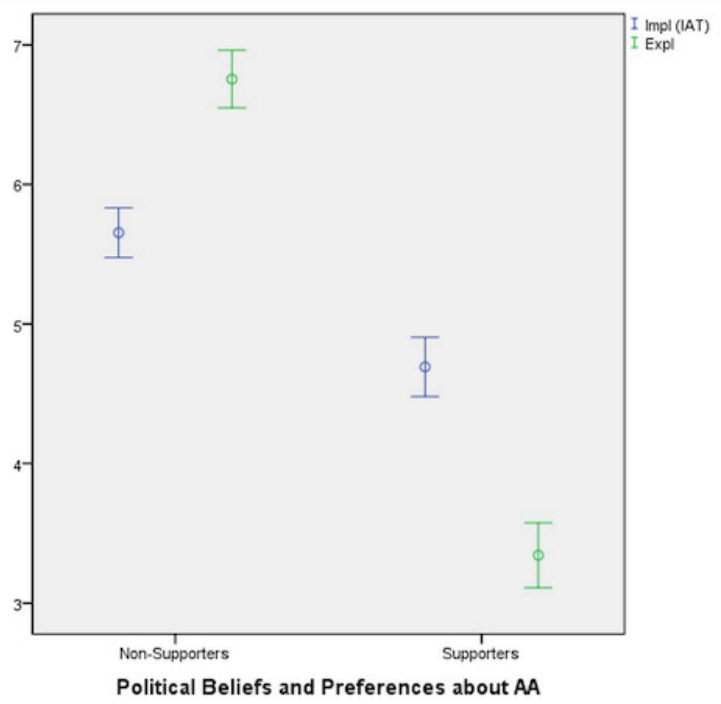

Finally, Figure 3 shows the effect of prejudice on our explicit and implicit measures. We find a small effect for prejudice on the implicit measure $(F(1,490)=13.19, p<0.001, r=$ 0.16), with high-prejudiced participants showing a greater implicit preference for the vestibular $(\mathrm{M}=5.56, \mathrm{SD}=1.70)$ than low-prejudiced participants $(M=5.00, S D=1.55)$. We also find a moderate effect for prejudice on the explicit measure $(F(1,490)=71.43, p<0.001, r$ $=0.36$ ), with high-prejudiced participants also reporting a greater explicit preference for the vestibular $(M=6.35, S D=1.96)$ than lowprejudiced participants $(M=4.50, S D=2.42)$. The within-group analysis also reveals that there are significant differences between implicit and explicit measures. Specifically, high-prejudiced participants tend to over-report their explicit support for the vestibular while low-prejudiced participants, for their part, tend to under-report it. 


\section{Figure 3}

Comparison of the explicit and implicit measures about the traditional entry exam (vestibular) by level of prejudice; data shown are means and 95\% confidence intervals.

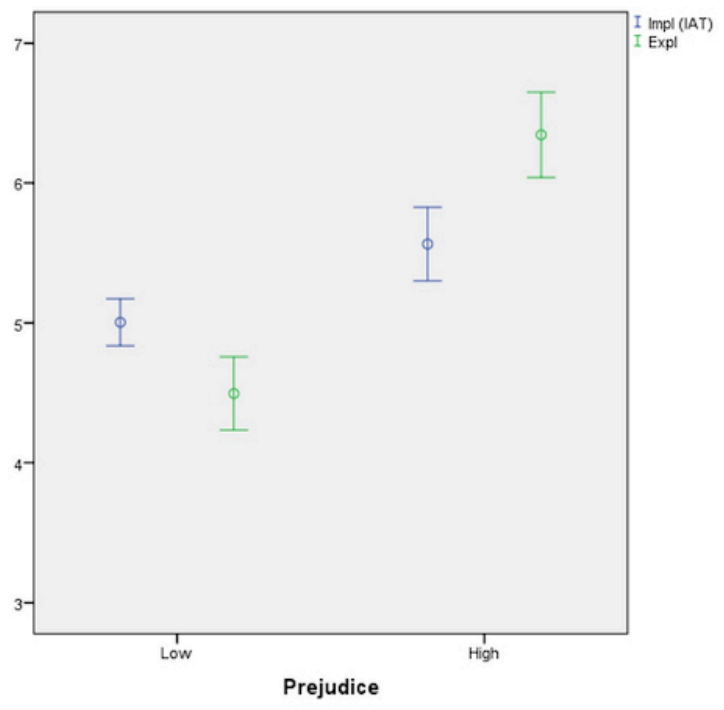

\section{Discussion}

This research aims to shed some light on the interplay between implicit and explicit attitudes on AA policies and explore how such attitudes relate to race, political preferences, and prejudice in a context where AA policies are essential, but little understood. We find that race, political beliefs and preferences about AA, and prejudice are all correlated, and in ways expected, with both our implicit and explicit measures about the traditional entry exam (vestibular). Specifically, 1) whites, as compared to non-whites, show slightly higher implicit and explicit support for the vestibular; 2) participants holding beliefs and preferences more supportive of AA tend to show lower implicit and explicit support for the vestibular, as compared to those holding less supportive beliefs and preferences; and, 3) high-prejudiced participants, as compared to lowprejudiced participants, exhibit higher implicit and explicit support for the vestibular.

We find that the relationship between implicit and explicit attitudes is strongly influenced by political beliefs and preferences about AA and prejudice, but, surprisingly, race does not exert a strong influence. Previous research has shown that attitudes on AA policies depend upon whether or not the individual is a member of the affected group, i.e., is a beneficiary of the policy (Telles \& Bailey, 2002). Our results are in line with this finding, but, surprisingly, we find only a minimal effect for race, as compared to other determinants. The differences in effect sizes between race, political beliefs and preferences, and prejudice are considerable and reinforce the importance of grounding statistical reasoning on more than alpha values (Cumming, 2014). The smaller effect of race can be a result of the high level of miscegenation in the Brazilian population, leading Brazilians who share common characteristics (e.g., skin tone) to self-categorize themselves in different racial groups. As a result, it dilutes the effect of race, at least, as compared to other societies with higher (past) racial segregation.

Our results provide evidence that other variables are more important than race to explain the interplay between attitudes about the admission system. In particular, we find that participants more supportive of AA tend to under-report their explicit support for the vestibular, as compared to their implicit support. Among those participants less supportive of AA, we find the opposite pattern, with an overreporting of the explicit support, as compared to the implicit one. We believe that this pattern is a way for participants to explicitly demonstrate their political point of view because participants have less control over the implicit measure. This finding raises some concerns about the use of explicit measures to gauge attitudes about AA.

A similar pattern is observed among high and low-prejudiced participants. Precisely, we find that high-prejudiced participants tend to overreport their explicit support for the vestibular, as compared to their implicit support. Among lowprejudiced participants, on the other hand, we find an under-reporting of the explicit support for the vestibular, as compared to the implicit one. This result suggests that low and high prejudiced individuals tend to explicitly demonstrate their position more strongly than their implicit support 
show. These patterns of under and over-reporting are potentially the results of the IAT measure that is less vulnerable to attempted manipulation (Steffens, 2004), at least as compared to explicit attitudes measures. Our findings are in line with the work by Gawronski et al. (2015) that note that the IAT is particularly helpful when dealing with socially sensitive issues like AA. To be sure, the discrepancies observed between the implicit and explicit measures suggest that the IAT technique can help to improve our understanding of attitudes on affirmative action.

Past research has shown that the object domain is one important determinant of the correlation between implicit-explicit attitudes (Nosek, 2007). We also know that groups with previously known attitudes about a specific object may show different explicit and implicit attitudes. Our findings of AA policies in Brazil are in line with these previous findings. The issue of AA policies represents a complex object domain because it involves considerations beyond race like values about meritocracy, access to resources, social justice, prejudice, and, of course, concerns about social desirability. The important discrepancies we find between our implicit and explicit measures on the vestibular is an illustration of this domain complexity.

Our results, although suggestive, should be interpreted cautiously, given two important limitations of our research design. First, our study recruited a convenience sample of volunteers. Presumably, these participants may hold different attitudes about racial quotas and the vestibular than the average university student. They may also hold strong attitudes about the admission process, contributing to their decision to take part in our study. Second, our recruited participants all come from the same university, a university where the issue of racial quotas has been on the agenda and discussed extensively for more than 10 years. Our results could potentially be different in other contexts where AA policies are a novelty. Thus, we must be cautious about the generalizability of our results and encourage the replication of our study in other contexts and adopting probabilistic samples.
Finally, our study adds to others in the evaluation of AA policies (e.g., Debell, 2016) and provides paths to improve them. Our study has contributed to the debate about AA by demonstrating the need also to explore the implicit attitudes of people affected by such policies. Our findings show that implicit and explicit attitudes on AA are related to race, as past work has shown, but also to other factors like political beliefs and preferences and prejudice. Taking into account these factors help in understanding how support for AA policies is developed and maintained, especially in a context where AA policies have already been widely implemented.

\section{Acknowledgements}

Ronaldo Pilati was supported by a grant (308268/2016-4) from the National Council for Scientific and Technological Development (CNPq). Mathieu Turgeon was also supported by a grant (406137/2016-1) from the National Council for Scientific and Technological Development (CNPq).

\section{References}

Bar-Anan, Y., \& Nosek, B. A. (2012). A comparative investigation of seven implicit measures of social cognition. SSRN Electronic Journal. Retrieved from https://ss rn.com/abstract $=2074556$

Bailey, S. R., Fialho, F, \& Peria, M. (2015). Support for race-targeted affirmative action in Brazil. Ethnicities. Advance online publication. https://doi.org/10.1177/14687 96814567787

Bos, L., Sheets, P., \& Boomgaarden, H. G. (2018). The Role of Implicit Attitudes in Populist Radical-Right Support. Political Psychology, 39(1), 69-87. https://doi.org/10.1111/pops. 12401

Cumming, G. (2014). The new statistics: Why and how. Psychological Science, 25(1), $7-$ 29. https://doi.org/10.1177/095679761350 4966 
Debell, M. (2016). Polarized opinions on racial progress and inequality: Measurement and application to affirmative action preferences. Political Psychology, 38, 481-498. https://doi.org/10.1111/pops.123 42

de Rezende-Pinto, J. M. (2004). O acesso à educação superior no Brasil [Access to Higher Education in Brazil]. Educação $\mathcal{E}$ Sociedade, 25(88), 727-756. https://doi.org/ 10.1590/S0101-73302004000300005

dos Santos, J. T. (2012). Cotas nas universidades: Análises dos processos de decisão [University quotas: Analysis of the decision processes]. Salvador: UFBA.

Friese, M., Smith, C. T., Koever, M., \& Bluemke, M. (2016). Implicit Measures of Attitudes and Political Voting Behavior. Social and Personality Psychology Compass, 10(4), 188-201. https://doi.org/10.1111/spc 3.12246

Gawronski, B., Galdi, S., \& Arcuri, L. (2015). What can political psychology learn from implicit measures? Empirical evidence and new directions. Political Psychology, 36(1), 1-17. https://doi.org/10.1111/pops.12094

Greenwald, A. G., Nosek, B. A., \& Banaji, M. R. (2003). Understanding and using the Implicit Association Test: I. An improved scoring algorithm. Journal of Personality and Social Psychology, 85(2), 197-216. https://d oi.org/10.1037/0022-3514.85.2.197

Hahn, A., \& Gawronski, B. (2018). Implicit Social Cognition. In S. Ghetti (Ed.), Stevens' Handbook of Experimental Psychology and Cognitive Neuroscience (Vol. 4, pp. 1-33). Hoboken, NJ, USA: John Wiley \& Sons, Inc. https://doi.org/10.1002/ 9781119170174.epcn412

Hofmann, W., Gschwendner, T., Nosek, B. A., \& Schmitt, M. (2005). What moderates implicit-explicit consistency? European Review of Social Psychology, 16(1), 335-390. doi: $10.1080 / 10463280500443228$

Htun, M. (2004). From "racial democracy" to affirmative action: Changing state policy on race in Brazil. Latin American Research
Review, 39(1), 60-89. https://doi.org/10.135 3/lar.2004.0010

Kang, J., \& Banaji, M. R. (2006). Fair measures: A behavioral realist revision of "affirmative action". California Law Review, 94(4), 1063-1118. https://doi.org/10.2307/204390 59

Karpen, S. C., Jia, L., \& Rydell, R. J. (2012). Discrepancies between implicit and explicit attitude measures as an indicator of attitude strength. European Journal of Social Psychology, 42 (1), 24-29. https://doi.org/10. 1002/ejsp.849

Kim, S. H. \& Kim, S. (2016). Social Desirability Bias in Measuring Public Service Motivation. International Public Management Journal, 19(3), 293-319. https: //doi.org/10.1080/10967494.2015.1021497

Kravitz, D. A., Harrison, D. A., Turner, M. E., Levine, E. L., Chaves, W., Brannick, M. T., ... Conard, M. A. (1997). Affirmative action: A review of psychological and behavioral research. Bowling Green, $\mathrm{OH}$ : Society for Industrial and Organizational Psychology.

Kuklinski, J., Sniderman, P., Knight, K., Piazza, T., Tetlock, P., Lawrence, G., \& Mellers, B. (1997). Racial Prejudice and Attitudes Toward Affirmative Action. American Journal of Political Science, 41 (2), 402-419. h ttps://doi.org/10.2307/2111770

Ksiazkiewicz, A., Vitriol, J., \& Farhart, C. (2018). Implicit Candidate-Trait Associations in Political Campaigns. Political Psychology, 39(1), 177-195. https://doi.org/10.1111/po ps. 12398

Modesto, J. G. N., \& Pilati, R. (2015). Implicit deservingness: Implicit association test for belief in a just world. Interamerican Journal of Psychology, 49(2), 203-212. Retrieved from http://www.redalyc.org/articulo.oa?id $=28446019006$

Nosek, B. A. (2007). Implicit-explicit relations. Current Directions in Psychological Science, 16(2), 65-69. https://doi.org/10.1111/j.146 7-8721.2007.00477.x

Nosek, B. A., Hawkins, C. B., \& Frazier, R. S. (2011). Implicit social cognition: 
from measures to mechanisms. Trends in Cognitive Sciences, 15(4), 152-159. https:// doi.org/10.1016/j.tics.2011.01.005

Raccuia, L. (2016). Single-Target Implicit Association Tests (ST-IAT) Predict Voting Behavior of Decided and Undecided Voters in Swiss Referendums. PLOS ONE, 11(10), e0163872. https://doi.org/10.1371/journal. pone. 0163872

Schmermund, A., Sellers, R., Mueller, B., \& Crosby, F. (2001). Attitudes toward affirmative action as a function of racial identity among African Americans. Political Psychology, 22 (4), 759-774. https://doi.org/ 10.1111/0162-895X.00261

Sniderman, P. M., \& Grob, D. B. (1996). Innovations in experimental design in attitude surveys. Annual Review of Sociology, 22(1), 377-399. https://doi.org/10.1146/an nurev.soc.22.1.377

Sniderman, P. M., Crosby, G. C., \& Howell, W. G. (2000). The politics of race. In: D. O. Sears, J. Sidanius \& L. Bobo (Eds.), Racialized politics: The debate about racism in America (pp. 236-279). Chicago, IL: The University of Chicago Press

Steffens, M. C. (2004). Is the implicit association test immune to faking? Experimental Psychology, 51(3), 165-179. https://doi.org/ 10.1027/1618-3169.51.3.165

Stein, L. M., \& Gomes, C. F. (2009). Normas brasileiras para listas de palavras associadas: Associação semântica, concretude, frequencia e emocionalidade [Brazilian norms for word lists: Semantic Association, concreteness, word frequency, and emotionality]. Psicologia: Teoria e Pesquisa, 25(4), 537-546. https://doi.org/10 $.1590 /$ S0102-37722009000400009

Telles, E., \& Bailey, S. (2002). Políticas contra o racismo e opinião pública: comparações entre Brasil e Estados Unidos [Anti-racismo policies and public opinion: Comparisons between Brazil and United States]. Opinião Pública, 8(1), 30-39. https://doi.org/10.159 0/S0104-62762002000100002

Theodoro, M., Jaccoud, L., Osório, R. G., \& Soares, S. (2009). As políticas públicas e a desigualdade racial no Brasil 120 anos após a abolição [Public policies and racial inequality in Brazil 120 years after slavery abolition]. Brasília: IPEA.

Theodoridis, A. G. (2017). Me, Myself, and (I), (D), or (R)? Partisanship and political cognition through the lens of implicity identity. The Journal of Politics, 79(4), 1253-1267. Retrieved from https://pages.ucsd.edu/ mboyle/ COGS2/readings/Me,\%20Myself,\%20and\% 20(I), \%20(D), \%20or\%20(R)\%20Partisan ship\%20and\%20Political\%20Cognition\% 20through\%20the\%20Lens\%20of\%20Impli cit\%20Identity.pdf

Turgeon, M., Chaves, B. S., \& Wives, W. W. (2014). Políticas de ação afirmativa e o experimento de listas: o caso das cotas raciais na universidade brasileira [Affirmative action policies and the list experimente: The case of racial quotas in brazilian university]. Opinião Pública, 20(3), 363-376. https://doi.org/10.1590/1807-019 12014203363

Vidigal, R. (2018). Affirmative Action Attitudes of Whites: Evidence from a List Experiment Survey in Brazil. Brazilian Political Science Review, 12(2), e0003. https://doi.org/10.15 90/1981-3821201800020003

\section{Notes}

* Research article. 